Goldschmidt 2021 Abstract

https://doi.org/10.7185/gold2021.8112

\section{Possible ways to origin thucholites. Are thucholites the first example of the geological convergence?}

MARCIN DANIEL SYCZEWSKI ${ }^{1}$, PAWEŁ PANAJEW ${ }^{2}$, FRANCISZEK CZECHOWSKI ${ }^{3}$, ANDRZEJ BORKOWSKI ${ }^{4}$, JAN ROHOVEC ${ }^{5}$, ŠÁRKA MATOUŠKOVÁ ${ }^{5}$, ILONA SEKUDEWICZ ${ }^{6}$, MALWINA LISZEWSKA ${ }^{7}$, BARTŁOMIEJ JANKIEWICZ $^{7}$, ALIYA MUKHAMEDIAROVA ${ }^{8}$ AND MIROSŁAW SŁOWAKIEWICZ ${ }^{1,8}$

${ }^{1}$ University of Warsaw

${ }^{2}$ KGHM Polska Miedź S.A.

${ }^{3}$ University of Wrocław

${ }^{4}$ AGH University of Science and Technology

${ }^{5}$ Institute of Geology, Czech Academy of Sciences

${ }^{6}$ Institute of Geological Sciences, Polish Academy of Sciences

${ }^{7}$ Military University of Technology

${ }^{8}$ Kazan Federal University

Presenting Author: marcinsyczewski@uw.edu.pl

The thucholites are mineraloids that consist of a mixture of hydrocarbons, Th, U, C, and $\mathrm{H}$. To nowadays are a few hypotheses about the origin of thucholites. One of the hypotheses of their formation is the sorption of uranium and thorium onto the hydrocarbons or organic matter, which were degraded by irradiation. In some cases, the formation of the thucholites is explained by microbial activity in the sedimentary basin. However, there is no clear evidence for considering any of these hypotheses to be dominant.

The samples of thucholites for further investigations were collected in the polymetallic deposit of the copper mine. The mine is located on the Fore-Sudetic Monocline. Investigated thucholites occur in the dolomitic shales, which belong to copper-breeding shales of the Lower Zechstein (PZ1) rock formation. The aggregations of thucholite in shales are present as scattered, spherical, or granular concretions. To suggest the possible origin of thucholites, the analyses using the SEM-EDS, EPMA, ICP-OES, HR-ICP-MS, XRD, Raman spectroscopy, GCMS, Pyro-GC-MS, CHNS, and Rock-Eval were carried out. The obtained results suggest that the origin of thucholites may be related to the sorption of thorium and uranium onto charcoals, coals, or heavily carbonized organic matter. However, these conclusions do not explain the formation of the origin of the thucholites from Viitaniemi pegmatite [1] in Finland or sandstones from the Witwatersrand deposit [2]. Therefore, the question arises whether the thucholites are the first example of geological convergence?

References:

[1] Golowin, R., Holzheid, A., Sönnichsen, F.D., Chukanov, N.V., 2014. Formation of solid bituminous matter in pegmatites: Constraints from experimentally formed organic matter on microporous silicate minerals. Geochemistry 74, 343-351. https://doi.org/10.1016/j.chemer.2013.08.006

[2] Mossman, D.J., Minter, W.E.L., Dutkiewicz, A., Hallbauer, D.K., George, S.C., Hennigh, Q., Reimer, T.O.,
Horscroft, F.D., 2008. The indigenous origin of Witwatersrand "carbon." Precambrian Res. 164, 173-186.

https://doi.org/10.1016/j.precamres.2008.04.008 